\title{
Measuring The Accomodation of Sharia Principles in Determining the Pricing of Consumer Financing Products of BSM (Sharia Mandiri Bank)
}

\author{
Syaparuddin \\ State College of Islamic Studies of Watampone \\ safarb135@gmail.com
}

\begin{abstract}
This study is intended to evaluate the pricing determination of consumer financing products of BSM, so that the customers can find out if BSM provides a treatment of installment payments on consumer financing products in accordance with sharia principles. In establishing the pricing on consumer financing products, BSM uses two methods, namely: the annuity method and the proportional (flat) method. The Construction of pricing on the consumer financing products in BSM is based on: (a) the total of installment payment per-month, it is based on financing platfond, percentage of margin, and period of time, $(b)$ the principal installment payment per-month, it is based on total of principal installment payment per-month, and margin, (c) the installment payament of profit margin per-month, it is based on platfond, principal, and percentage of margin. The pricing used by BSM needs to be revitalized because (a) there is a profit return factor for customers, (b) containing a gharar element, and (c) using the paradigm of conventional bank in setting pricing.
\end{abstract}

\begin{abstract}
Abstrak
Kajian ini dimaksudkan untuk mengevaluasi penetapan pricing produk pembiayaan konsumen di BSM, agar nasabah dapat mengetahui apakah BSM memberikan perlakuan angsuran pembayaran pada produk pembiayaan konsumen sudah sesuai dengan prinsip syariah. Dalam menetapkan pricing pada produk pembiayaan konsumen, BSM menggunkan dua metode, yaitu: metode annuitas dan metode proporsional (flat). Basis konstruksi penetapan pricing pada produk pembiayaan konsumen di BSM, yaitu: (a) total angsuran per-bulan nasabah, yaitu: platfond pembiayaan, persentase marjin, dan jangka waktu, (b) angsuran pokok per-bulan nasabah, yaitu: total angsuran pokok per-bulan, dan marjin keuntungan, (c) angsuran marjin keuntungan per-bulan nasabah, yaitu: platfond, angsuran pokok, dan persentase marjin. Penetapan pricing tersebut perlu direvitalisasi karena (a) ada faktor pengembalian beban keuntungan bagi nasabah, (b) mengandung unsur gharar, dan (c) menggunakan paradigma bank konvensional dalam menetapkan pricing.
\end{abstract}

Keywords: Pricing, Product, Finance, Consumer, BSM 


\section{A. Introduction}

Sharia bank is a financial institution that is managed on the basis of sharia rules, in other words, the management of sharia bank is based on sharia values, principles and concepts that are not specifically intended for a group of people but according to the Islamic foundation of Rahmatan li al-'âlamin (grace for the universe) which was established to serve the public without distinguishing the beliefs held. For muslims, the presence of Sharia banks is to meet their needs of financial transactions islamically, but for non muslim communities, Sharia banks are as an alternative financial institutions in addition to conventional banks that have long existed.

Ideally, in addition to being required to comply with sharia principles, Sharia banks are also expected to provide returns to the owners of third party funds at least equal to, or even greater than the interest rate applicable in conventional banks and set lower profit margins than interest rates of credit in conventional banks. Sharia banks apply profit margins on consumer financing products in the form of murâbahah contracts, i.e. business contracts that provide payment certainty, both in terms of amount and timing. These financing products according to Muhammad: (1) the cash flow must be or have been agreed at the beginning of the contract, (2) the exchange object is also certain in quantity, quality, time and price. ${ }^{1}$

Technically, the profit margin as mentioned above according to Karim, can be defined as a ceratin percentage set per year. If the calculation of profit margin is set daily, the number of days in a year is set 360 days, but if the calculation of profit margin is set montly, a year is set 12 months. $^{2}$

To realize the above profit margin in accordance with sharia principles, sharia banks must internalize the principles of amânah, shiddiq, fatânah, and tabligh in establishing pricing policies on consumer financing products, so that sharia banks can provide maximum return to the owners of third party funds. The higher return obtained by the bank, the higher margin can be provided by the bank to the owners of third

\footnotetext{
${ }^{1}$ Muhammad, Manajemen Keuangan Syari'ah: Analisis Fiqh \& Keuangan, Ed. I, Cet. I (Yogyakarta: UPP STIM YKPN, 2014), p. 271.

${ }^{2}$ Adiwarman A. Karim, Bank Islam: Analisis Fiqih dan Keuangan, (Ed. 3-4; Jakarta: PT RajaGrafindo Persada, 2007), p. 15.
} 
party funds and vice versa. However, Sharia Mandiri Bank (BSM) ${ }^{3}$ in determining the pricing of consumer financing products in the form of murâbahah contracts will not be able to fully accommodate the principles of amânah, shiddiq, fatânah, and tabligh as mentioned above, so that the financing products are considered to be more or less the same as interestbased financing products in conventional banks. ${ }^{4}$

Thus, if the determination of pricing on consumer financing products in BSM has not been in accordance with sharia principles, this can lead to negative opinion in the public that sharia banks are just like conventional banks in providing financing profits to their customers. Therefore, BSM should evaluate it and can provide clear and detailed information to the public about the pricing of consumer financing products applied. On this basis, the issues raised in this paper are: (1) what kind of method is used by BSM in determining the pricing of consumer financing products, (2) can the pricing method provide a fair profit margin to its customers according to sharia principles?

These are very urgent to study because the determination of fairer pricing and inconsistent with the sharia principles may influence the choice and the emotion of public. If the interest rate is greater than the profit margin, especially if the margin determination is in accordance with the principles of sharia, the public will prefer to take financing products in sharia bank and vice versa if the interest rate is lower than the profit margin and also the determination of the margin is less in line with sharia principles, the public will prefer to take credit in conventional bank. It means that the choice of public is profit-motivated and islamically emotional in taking a consumer financing products offered by the bank.

\section{B. Sharia Principles of Transactions}

Along with the development of the society's economy in this contemporary era, they have many needs of goods and services to meet as well. With the increasing of their needs of goods and services, they want to meet them immediately. Because if those needs can not be met,

\footnotetext{
${ }^{3}$ This study was done at the head office of BSM and the type of data given by BSM to the writer was a secondary data, so the object of this study is the head office of BSM.

${ }^{4}$ The results of observations done by the writer on documents and public perceptions related to consumer financing products in the form of murâbahah contracts at the head office of BSM on May 1-31, 2016.
} 
the managed business will go bankrupt or will get a lower income. If they are urgent, the producers or sellers seek alternatives to make the transaction system easy. In sharia principles stated that all things are prohibited, except for the provisions based on the Koran and Hadith. While in the affairs of transactions, everything is allowed unless there is a prohibition that prohibits it. This means that when a new transaction emerges and is not previously known in sharia principles, it is deemed acceptable, unless there is an implication of a postulate the Quran and Hadith which forbids it, either explicitly or implicitly. Thus, in the field of muâmalah, all transactions are allowed except forbidden. ${ }^{5}$

In sharia principles, a transaction prohibited is due to its substance and other than its substance which are prohibited and also its contract is not valid. The explanation about these can be presented as follows: ${ }^{6}$ the substances prohibited such as liquor, carrion, pork, and so forth. So, the sale and purchase of liquor as mentioned above are prohibitted, although the sale contract is legal. While prohibitted other than the substance is divided into two forms: First, Breaking the principle of 'an-tarâdhin minkum, i.e. violating by means of deception (tadhlîs) which means that one party does not know the information known by the other. They should have the same information so that no one feels cheated. This can happen in four ways:

1. Quantity, for example: The seller reduces scales.

2. Quality, for example: The seller conceals defective goods offered.

3. Price, for example: Exploiting buyer's ignorance of market price by raising product price above market price.

4. Delivery time, for example: The consultant has promised to complete the project within two months, even though he knows that the project can not be completed in two months.

Second, Breaking the principle of lâ tazhlimûna wa lâ tuzhlamûn. The practices that violate this principle are: ${ }^{7}$

1. Taghrîr. Taghrîr which is also called gharar, is a situation where it occurs because of the uncertainty of both parties who transact.

2. Market engineering in supply. This happens when a producer/seller takes normal profit by reducing the supply so that the price of the

\footnotetext{
${ }^{5}$ Adiwarman A. Karim, Bank Islam: Analisis Fiqih dan Keuangan, p. 29.

${ }^{6}$ Ibid., p. 30-48.

${ }^{7}$ Asyraf Wajdi Dusuki, Sistem Keuangan Islam: Prinsip dan Operasi, Cet.1 (Jakarta: PT. RajaGrafindo Persada, 2015), p. 213-220.
} 
product he sells rises, in Islamic law term is called ikhtikâr. Ikhtikâr occurs when the conditions below are met, namely: (a) Striving for the scarcity of goods by stockpiling stock, (c) Selling at higher prices than the price before the emergence of scarcity, and (c) Taking a higher profit.

3. Market engineering in demand. This happens when a producer or a buyer creates a false request, as if there is a lot of demand for a product so that the selling price of the product will rise, in Islamic law term called bâi najasy.

4. Usury. Usury is the most important topic because its prohibition has been agreed upon in Sharia principles. Usury is divided into 3 main parts namely: (a) Ribâ Fadhl. An usury which is applicable in the sale and purchase based on the excess on one of the similar treasures traded by the measure of syara'. The measure of syara' meant is a certain weigh or measure. (b) Ribâ Nasîah. This usuary is the most extreme type of transactions for its prohibition and tyranny, namely the buying and selling include the exchange of certain doses of food with a certain dose until a certain time, or not directly, (c) Riba Qardh. This usury is one type of usury in which a person lends some money to another, and requires the lender to return greater than what he has lent, or to return with something better and more perfect or the one who lends money to sue to the party lent to take advantage of his home, or other things.

5. Maîsir (gambling). Simply meant by gambling is a game that specifies one party must bear the burden of the other party due to the game.

6. Risywah (bribe). Risywah is an act that gives something to the other party to get something that is not his right.

Another cause of a transaction prohibited according to sharia principles is that if its contract is invalid or incomplete. The incomplete contract may occur if there is one (or more) of the factors below, they are: ${ }^{8}$

1. Pillar and requirement. Pillar is one of the things that must exist in a transaction whereas the requirement is something that its existence complements the pillar. So if the pillar has been fulfilled but the

\footnotetext{
${ }^{8}$ Syamsul Anwar, Hukum Perjanjian Syariah: Studi tentang Teori Akad dalam Fikih Muamalah, Ed.1, Cet.1 (Jakarta: PT. RajaGrafindo Persada, 2007), p. 95-105.
} 
requirements are not met, the pillar will be incomplete so the transaction becomes invalid.

2. Ta'alluq. This happens when faced with two contracts that are linked to each other then the validity of one contract depends on the second contract. Example A sells the car for 120 million in installments to B on condition that B must resell the car to A in cash for 100 million. Such transactions are forbidden, because there is a requirement that A must be willing to sell the car to B as long as B resells the car to A. In this case it is required that one contract will be effective when the two contracts are made. The application of this condition prevents the fulfillment of pillar, in Islamic law this case is called baî 'al 'inah.

3. Two in one, is a transaction which has two contracts at once, and this results in uncertainty (gharar) about which contract to use (apply), this event is called shafqataîn fi al-shafqah.

\section{Consumer Financing Products of BSM}

Consumer financing products provided by BSM are BSM Implant Financing, Medical Equipment Financing, BSM Education Financing, Pension Funding Financing, Employee Cooperative for Members, Griya BSM Financing, Griya BSM Subsidy Financing, Vehicle Financing. For more details about their descriptions can be presented as follows: ${ }^{9}$

First, BSM Implant Financing. BSM Implan Financing is consumer financing in rupiah currency granted by the bank to permanent employees of the Company whose filings are made in bulk (group). BSM Implan Financing can accommodate the financing needs for company employees, for example the company does not have employee cooperatives, employee cooperatives have not experienced in saving and loan activities, or the companies with limited number of employees. ${ }^{10}$

BSM Implant Financing is designated: (1) to purchase consumer goods (halal), (2) to purchase/obtain benefits for services (e.g. for the cost of education funds). Benefits of BSM Implan Financing are: (1) for

\footnotetext{
${ }^{9}$ The results of observations done by the writer on documents and public perceptions related to consumer financing products in the form of murâbahah contracts at the head office of BSM on May 1-31, 2016, and also see Sharia Mandiri Bank (BSM), "Consumer Banking Products", Internal Documents, Sharia Mandiri Bank, Sited from http//: www.syariahmandiri.co.id, on January 2, 2017.

${ }^{10}$ Ibid.
} 
company, one of the rewards to employees and outsourcing the source of funds and loan administration, (2) for employees, the opportunity and ease of obtaining financing facilities. The contracts of BSM Implan Financing used are: (1) Wakâlah wa al-Murâbahah for purchasing goods, (2) Wakâlah wa al-Ijârah to obtain benefits for services used. ${ }^{11}$

Second, Medical Equipment Financing. Medical Equipment Financing is the provision of financing facilities to medical/health professionals for the purchase of medical equipments. The contract used is Murâbahah. Murâbahah contract is a buying and selling contract between the bank and the customer, where the bank buys the required goods and sells it to the customer at the cost of the principal plus the agreed margin profit. The benefits of this financing are: (1) financing the needs of customers (medical professionals) in the procurement of medical equipments, (2) the customer can repay the payment by the number of installments that will not change during the term of concract. ${ }^{12}$

Third, BSM Education Financing. BSM Education Financing is short-and medium-term financing used to meet the needs of school entrance fees/colleges/ other educational institutions or tuition fees upon enrollment of the new academic year/next term with ijârah contract. The benefits of this financing are: (1) in accordance with sharia principles, (2) light and fixed installments, (3) quick and easy process, (4) light administration fee, and (5) collateral free up to Rp. 250 million specifically for employees with certain requirements. ${ }^{13}$

Fourth, Financing to Pensioners. Financing to Pensioners is the distribution of consumer financing facilities (including multipurpose financing) to the lenders, with installment payments made through direct pension deduction received by the bank each month (monthly pension). The contract used is akad murâbahah or ijârah. The benefits of this financing are: (1) providing opportunities and facilities to obtain financing facilities, (2) improving the quality of life of customer with installment payment system through direct cut of monthly pension received every month. ${ }^{14}$

Fifth, Financing to Cooperatives. This financing is the distribution of financing to/through employee cooperatives to meet the

\footnotetext{
${ }^{11}$ Ibid.

${ }^{12}$ Ibid.

${ }^{13}$ Ibid.

${ }^{14}$ Ibid.
} 
needs of its members (collective) who apply for financing through employee cooperatives. The benefits of this financing are: (1) outsourcing of funding sources and loan administration, (2) the cooperative can obtain the share of installment paid by the customer, (3) the cooperative fund which is used for loan to member, can be transferred for the development of other productive business units. ${ }^{15}$

Sixth, BSM Griya Financing. Griya BSM financing is short, medium, or long term financing to finance the purchase of residential houses (consumer), both new and used, in the developer's environment with murâbahah contracts, namely buying and selling contract between the bank and the customer, where the bank buys the required items and sells them to the customer at the principal price plus the agreed margin profit. The benefits of this financing are: (1) to finance the needs of customers in the case of procurement of new and used housing, (2) the customer can repay the payment by the amount of installment that will not change during the period of contract. ${ }^{16}$

Seventh, Subsidized Griya BSM Financing. Subsidized Griya BSM Financing is a financing for the ownership or purchase of a simple healthy house (RS Sehat/RSH) built by the developer with the support of a subsidized down payment facility from the government. The contract used is murâbahah. The benefits of this financing are: (1) to help increase customer's down payment so that the total amount of down payment paid by the customer is able to lower the financing ceiling to be paid monthly on a fixed basis with the margin, (2) repayment of the installments with unchanged installments over the contract. ${ }^{17}$

Eighth, BSM Vehicle Financing (PKB). BSM Vehicle Financing is a financing for the purchase of vehicles with murâbahah scheme. Financing that can be categorized as PKB are: (1) Type of vehicles: Cars and motorcycles, (2) Condition of vehicles: New and used. For new vehicles, the financing period is up to 5 years while the used vehicle is up to 10 years (calculated including the age of the vehicle and the term of financing). ${ }^{18}$

\footnotetext{
${ }^{15}$ Ibid.

${ }^{16}$ Ibid.

${ }^{17}$ Ibid.

${ }^{18}$ Ibid.
} 


\section{Methods and Formulation of Pricing}

Technically pricing meant here according to Karim, ${ }^{19}$ is determination of the selling price of an item while the margin is a certain percentage determined per year. If the calculation of profit margin is set daily, the number of days in a year must be 360 days but if it is set monthly, a year must be 12 months. Generally, financing customers pay installments. Claims arising from sale and purchase transactions and/or leases based on murâbahah, salâm, istishnâ' and or ijârah are referred to as debts. The amount of the debts depends on the financing plafond, i.e. the amount of financing (purchasing price plus prinsipal price of an item) contained in the financing contracts.

Determination of pricing on consumer financing products with murâbahah scheme according to Karim, ${ }^{20}$ is based on recommendations, proposals and suggestions from the ALCO (Asset Liability Commitee) team of Sharia Bank by taking into account the following references: (1) Direct Competitor's Market Rate (DCMR), the average profit margin level of sharia bank, or the average profit margin rate of several Sharia banks as defined in the ALCO meeting as a direct competitor group, or the level of profit margin of a particular sharia bank specified in ALCO meeting as the nearest direct competitor; (2) Indirect Competitor's Market Rate, i.e. the average interest rate of conventional banks, or the average interest rate of some conventional banks in the ALCO meeting is defined as indirect competitor group, or the average interest rate of certain conventional bank which in ALCO meeting is determined as the nearest indirect competitor, (3) Expected Competitive Return for Investors (ECRI), i.e. the target for the competitive outcome expected can be given to the third-party funds, (4) Acquiring Cost, i.e. costs incurred by banks directly related to efforts to obtain third-party funds, (5) Overhead Cost, i.e. cost incurred by banks that are not directly related to efforts to obtain third-party funds. The summary of the profit margin references can be presented in the figure below:

\footnotetext{
${ }^{19}$ Adiwarman A. Karim, Bank Islam: Analisis Fiqih dan Keuangan, p. 253.

${ }^{20}$ Ibid., p. 254-257.
} 
Figure 1: Profit Margin References

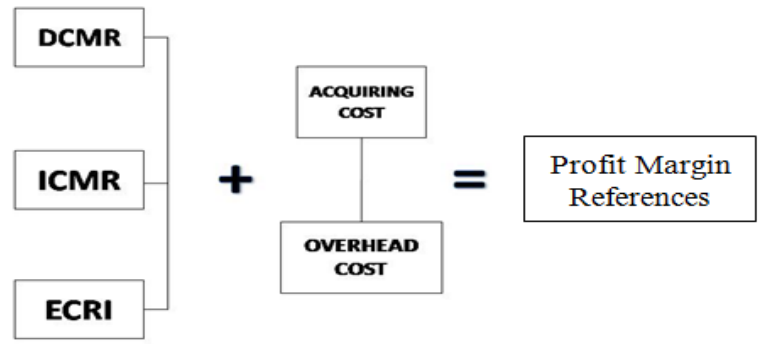

After obtainıng protit margin reterences, the bank determines the selling price. The selling price is the sum of the purchasing price/ principal price of an item/ price earned bank and the profit margin. The summary can be presented as shown below:

Figure 2: Formula of Bank's Selling Price

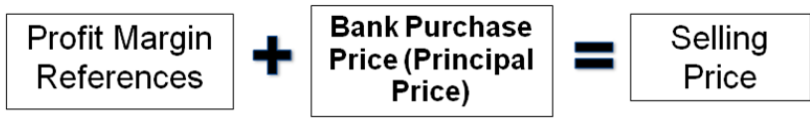

After that, Karim said that the bank will determine the installment of selling price. The installment of selling price consists of the installment of purchasing price/ principal price and the installment of profit margin. The determination of this type of installment can be calculated by using four methods, namely: First, Sliding Profit Margin Method. Sliding Profit Margin is the calculation of declining profit margin in accordance with the decrease in the cost of principal goods as a result of the installment/installment of principal price, the number of installments (principal price and profit margin) paid by customers every month decreases. Margin decreases due to the installment of purchasing price.

Figure 3: Sliding Profit Margin

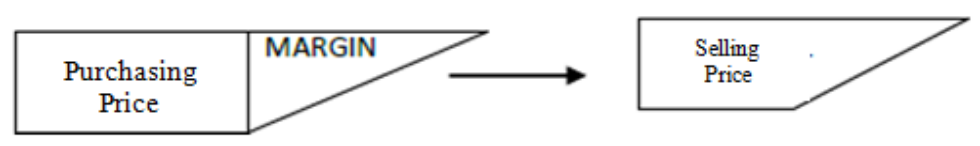

Second, Average Profit Margin. The Average Profit Margin is a declining profit margin whose calculations are fixed and the installment 
amount (principal price and profit margin) is paid monthly by the customer. Decreasing margins have been calculated regularly.

Figure 4: Average Profit Margin

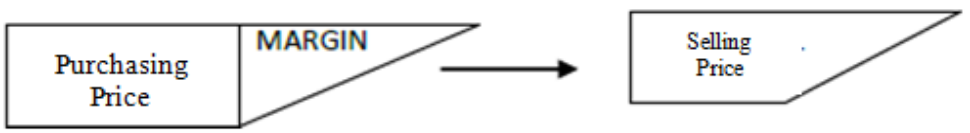

Third, Flat Profit Margin. Flat profit is the calculation of the profit margin on the value of the fixed cost of financing from one period to another, even though its debit decreases as a result of the principal installment.

Figure 5: Flat Profit Margin

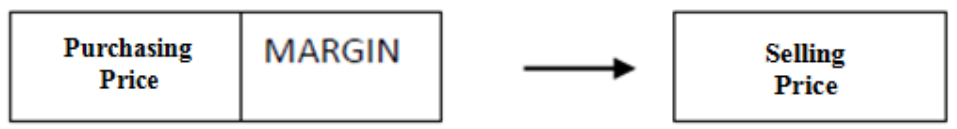

Fourth, Annuıty rroiı iviargin. Annuıty rroiı ivargin is the profit margin derived from the annuity calculation. The annuity calculation is a way of returning the financing with fixed installment payment and fixed profit margin. This calculation will result in an increasingly large pattern of basic price of commodity and a declining profit margin.

Figure 6: Annuity Profit Margin

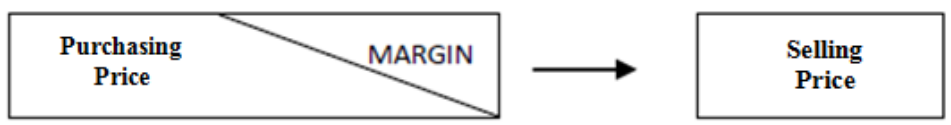

However, it needs to know that the profit margin $=\mathrm{f}$ (plafond) can only be calculated if the following components are available: (1) type of profit margin calculation, (2) financing plafond according to type, (3) financing time period, (4) rate of profit margin, and (5) billing pattern or due on bill (either principal price or profit margin).

Thus, the method of pricing determination on consumer financing products with murâbahah schemes in sharia bank is divided into four types, namely lower margin profit, average profit, flat (proposional) profit margin, and annuity profit margin. However, this pricing determination uses only two methods, namely: (1) Annuity method. The main installment is smaller at the beginning but upward and the margin installment is larger at the beginning but declining, i.e. refund financing by paying fixed installemnts of principal price and profit margin to the 
end. This calculation will result in an increasingly large pattern of principal price and a reducing profit margins, and (2) Proportional method. The portion of the principal and margin installment is fixed to the end, namely the calculation of the profit margin on the value of the principal price of financing is fixed from one period to another, even though the debit decreases as a result of the installment of the principal price. $^{21}$

BSM prefers to use annuity method from the two methods of calculation above, because it wants to get higher profit and can compete with other banks. In addition, BSM must also distribute profits to customers with a high profit portion as well. Associated with the formulation, BSM has standardized the formulation of pricing on consumer financing products with murâbahah schemes. Nevertheless, in this study the writter tries to analyze it about the construction of the pricing formulation. The formulation of pricing determination with annuity method used by BSM to find total monthly installments of customers, can be persented as shown below: ${ }^{22}$

$$
\text { Total Monthly Installments }=\operatorname{Px}\left(\frac{\frac{\mathrm{i}}{12}}{1-\left(1+\frac{\mathrm{i}}{12}\right)^{-t}}\right) \begin{aligned}
& \mathrm{P}=\text { Plafond } \\
& \mathrm{i}=\text { Persentage } \\
& \mathrm{t}=\text { Time periode }
\end{aligned}
$$

While the formulation used to find the monthly principal installments of customers is Monthly principal Installments = The Total of Monthly Principal Installments - Profit Margin, and the formulation used to find monthly profit margin installments of customers is

$$
\text { Monthly margin installment }=(\mathrm{P}-\mathrm{AP} \mathrm{ke}) \mathrm{x}\left(\frac{i}{12}\right) \quad \begin{aligned}
& \mathrm{P}=\text { Plafond } \\
& \mathrm{AP}=\text { Installment Prinsipal } \\
& \mathrm{i}=\text { Persentage }
\end{aligned}
$$

The simulation of the use of pricing formulation with annuity method used by BSM can be presented as the following case: For example, on July 1, 2016 Ali Sadikin (pseudonym, researcher) proposed

\footnotetext{
${ }^{21}$ The results of observations done by the writer on documents and public perceptions related to consumer financing products in the form of murâbahah contracts at the head office of BSM on May 1-31, 2016, and see also Sharia Mandiri Bank, "Determination of Pricing with Murâbahah Contracts," Internal Documents, Sharia Mandiri Bank, Sited from http//: www.syariahmandiri.co.id, on January 2, 2017.

${ }^{22}$ Ibid.
} 
consumptive financing in the form of home renovation to BSM. The ceiling financing proposed by him amounts to Rp 10,000,000 with a period of 12 months. Profit margin rate set by BSM with the ceiling financing and the time period proposed is $12.25 \%$ (ER Flat p.a 6.90\%). What is the monthly installment amount of Ali Sadikin? How much is the profit margin obtained by BSM? How much is the selling price?

The total monthly installment of Ali Sadikin can be presented as shown below:

$$
10.000 .000 \times\left(\frac{\frac{12.25 \%}{12}}{1-\left(1+\frac{12.25 \%}{12}\right)^{-12}}\right)=889.657,83
$$

While the installment of profit margin per month (First Month) is

$$
\left(10.000 .000 \times\left(\frac{12.25 \%}{12}\right)\right)=102.083,33
$$

and monthly principal installment (First Month) is 889.657,83 $102.083,33=787.574,50$.

Based on the above calculation shows that the total monthly installment of customers is Rp. 889,657.83. The profit margin of the customer in the first month amounted to Rp. 102,083.33, the nominal will continue to decrease until the installment due. While the principal installment in month-1 is about $\mathrm{Rp}$. 787,574.50, the nominal will continue to increase until maturity. The profit margin earned by BSM on this financing is Rp $675,894.00$. Thus, the selling price set by the bank amounted to $\mathrm{Rp} 10,675,894.00$. The installments of this pricing with annuity method can be presented in table form as below: 
Tabel 1: Installments of Annuity Calculation

\begin{tabular}{|c|c|c|c|}
\hline No. & $\begin{array}{c}\text { Monthly Principal } \\
\text { Installment }\end{array}$ & $\begin{array}{c}\text { Monthly Margin } \\
\text { Installment }\end{array}$ & $\begin{array}{c}\text { Total } \\
\text { Installment }\end{array}$ \\
\hline 1 & $787.574,50$ & $102.083,33$ & $889.657,83$ \\
2 & $795.614,32$ & $94.043,51$ & $889.657,83$ \\
3 & $803.736,22$ & $85.921,61$ & $889.657,83$ \\
4 & $811.941,03$ & $77.716,81$ & $889.657,83$ \\
5 & $820.229,59$ & $69.428,24$ & $889.657,83$ \\
6 & $828.602,77$ & $61.055,07$ & $889.657,83$ \\
7 & $837.061,42$ & $52.596,41$ & $889.657,83$ \\
8 & $845.606,42$ & $44.051,41$ & $889.657,83$ \\
9 & $854.238,66$ & $35.419,18$ & $889.657,83$ \\
10 & $862.959,01$ & $26.698,82$ & $889.657,83$ \\
11 & $871.768,38$ & $17.889,45$ & $889.657,83$ \\
12 & $880.667,68$ & $8.990,15$ & $889.657,83$ \\
& & $\mathbf{6 7 5 . 8 9 4 , 0 0}$ & $\mathbf{1 0 . 6 7 5 . 8 9 4 , 0 0}$ \\
\cline { 2 - 4 } & $\mathbf{1 0 . 0 0 0 . 0 0 0 , 0 0}$ & \multicolumn{2}{|c}{}
\end{tabular}

The mechanism of the determination pricing on consumer financing products using murâbahah scheme with the annuity method as mentioned above, BSM incorporates a profitability return factor for customer so that the margin applied to the customer becomes very high, and also in profit making on the formula used, contains a gharar element. Muhammad explained that if the percentage of profits keeps going with time, a price gharar will happen. ${ }^{23}$ BSM also uses a conventional bank paradigm, namely: The marginal determination done by BSM uses a fixed rate with annuity method where the determination of margin and principal debt charged each month is not the same, but the total repayment of each monthly installment remains the same until completed, i.e. the same as the flat rate method. This policy could be a public perception that the pricing determination between Sharia Bank and Conventional Bank is not different, even sometimes the price given by BSM is more expensive than Conventional Bank. Though customers want to get relief by transacting at BSM. However, customers are getting a higher price charge than they transact in Conventional Banks.

In addition, BSM considers overhead cost factors, cost of loanable funds, and target profit as a determinant of financing margins.

\footnotetext{
${ }^{23}$ Muhammad, Sistem Bagi Hasil dan Pricing Bank Syariah, Cet. I (Yogyakarta: UII Press Yogyakarta, 2016), p. 190.
} 
This indicates that the determination of margin in BSM is similar to the determination of credit level in Conventional Banks. These three variables are the decisive aspect for the Conventional Bank to take the interest rate charged on a loan. Overhead costs include labor costs, administrative and general costs, depreciation expenses, provisioning allowances for uncollectible earning assets, and other costs associated with bank operating expenses. Target profit considers risk premium and reserves for collectible receivables.

\section{E. Alternative Formulation of Pricing Determination}

In determining the pricing (p) of financing product for a consumer with a murâbahah contract, BSM should pay attention to three main factors, namely: the base price of purchasing from the main dealer (x), the covered costs (y), and a fair profit agreed by the bank and customer (z). The equation of this can be presented as follows: ${ }^{24}$

$$
p=x+y+z
$$

The cost to be covered (y), or the value incurred to bring the goods to the customer, is derived from the calculation of the ratio between the base price of purchasing (x) and the total of financing target for the current year budgeted by the bank (v) Which is then multiplied by the average operating cost of the current year that has been budgeted (c). The amount of total value of financing target for the current year (v) and the average operating expenses for the current year (c) is obtained from the Work Meeting and Corporate Budget (RKAP) of the bank in the related year, and the equation can be presented as follows:

$$
P=x+\left[\left(\frac{x}{v}\right) \cdot c\right]+z
$$

With this formula, the determination of pricing on consumer financing products with a murâbahah contract in BSM will avoid the fluctuation of interest rate and cost of fund concept, therefore margin is not defined by percentage so there is no separation between principal installment and margin installment applied by BSM, and there is only one value that is the saling price or rental price.

\footnotetext{
${ }^{24}$ In making the equation presented in this study, the writer refers to the book written Dale E. Varberg. See Dale E. Varberg, Calculus with Analytic Geometry, (New Jersey, USA: Prenctice-Hall, 1992), p. 47-61.
} 
Based on formula (2) above, the margin which will be accepted by the bank, can be presented as follows:

$$
m=\left[\left(\frac{x}{v}\right) \cdot c\right]+z
$$

The components that will affect the size of the margin received by the bank (m) are the base purchasing price (x), the total budget target for the current year budgeted by the bank (v), the average operating expenses for the current year that have been budgeted (c) and the fair profit agreed by the bank and the customer (z).

The values of $\mathrm{v}$ and $\mathrm{c}$ are fixed during the current year so mathematically the most important components that can affect the magnitude of the margin for a bank are the base price of purchasing or leasing (x), and the profit to be agreed ( $\mathrm{z})$. In this case, sharia banks are expected to buy the goods at a cheaper price than others so that the selling price to customers can compete with the credit in conventional banks. This can be done by fostering good relations with the agents of related goods, or much in demand by customers.

However, if the selling or leasing price of goods with this formula becomes higher than the credit price in conventional banks with the assumption that the basic purchasing price is cheaper. So it is necessary to review the existing values in the RKAP because it could have a markup value which is not rational, not in accordance with the actual conditions, so that this selling price formula always produces a high value. This can reduce the efficiency of the bank.

One way of handling this is by evaluating the average operating cost of the current year (c) recorded in the RKAP where no irrational mark-up value may occur. However, if the value of $\mathrm{c}$ has been changed, the selling price is still high then component $\mathrm{v}$, which is the total financing target of the current year budgeted by the sharia bank, needs to be considered. In addition to this, that is by lowering profit. If the profit falls to a minimum and the selling price is still higher than that of the conventional bank, then the target of financing volume at the same opersional should be enlarged. Therefore, the determination of the value in the RAKP must be done carefully and honestly, because it is not possible to change the value in the middle of the current year, in addition to disrupting the company's budget flow, it will also oppress the bank's customers. 
If the repayment time made by the customer is one-year, then the mortgage amount is $p / 12$ and the margin for the bank is m.n. Its simulation can be presented as follows: For example, Mr. Ahmadia wants to buy a car, and he has money about Rp. 10 million while the car price is Rp. 50,000,000. To overcome this matter, Mr. Ahmadia applies a vehicle financing with a murâbahah contract to shariah bank (BSM) about Rp. $40,000,000$. Bank's prediction about its operational cost in one year is Rp.100.000.000, the prediction of financing amount is Rp. 1,000,000,000 and an agreed profit is Rp. 4,000,000, and the financing duration is one year. How to solve this case? The financing data are: (1) The principal price of the car is Rp. 50.000 .000 , (2) the down payment paid by the customer is Rp. 10.000.000, (3) the rest paid by the bank is Rp. 40.000.000. The solution of this case can be done as in the following table:

\section{Tabel 2: Simulation of Alternative Formulas}

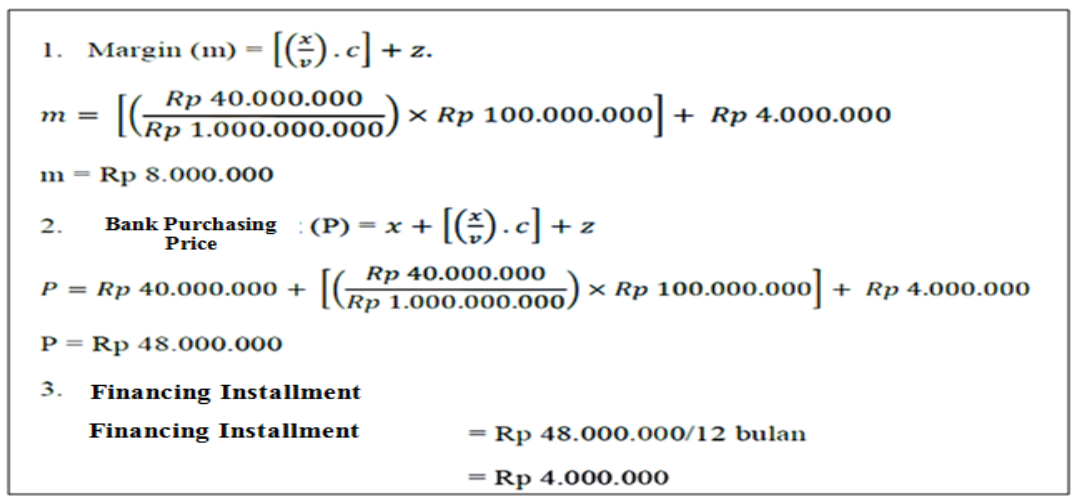

The results of calculation above show that the profits by using the proposed alternative formula show a better results than those used now in BSM, because the margin determination with this formula results from a reasonable profit after calculating total financing targets and total operating costs for one year, not based on the interest rate prevailing in the market or the interest rate of competitors so it will avoid from the fluctuations in interest rates.

This formula as an alternative model that is competitive. If this formula is used by BSM, it can open a wider market of customers and provide a positive outlook for increasing the company's revenue (bank). If this formula can be well disseminated to the community, BSM will be able to penetrate the large layers of Indonesian people who are still 
skeptical of the existence of sharia banks in general, and BSM in particular, because they already know that the pricing process in BSM is free from uncertain matters (gharar) and its value is lower than the credit value in conventional banks.

In addition, BSM should be able to improve the quality of its human resources that can provide a correct understanding to prospective customers to store or deposit funds in BSM. The more customers deposit their funds in BSM, the more financing can be disbursed to the community. Despite the profit earned is small but the profit will accumulate to be large as described on the previous page.

\section{F. Conclusion}

Based on the above discussion, the conclusions that can be drawn are: (1) Sharia Mandiri Bank (BSM) uses two methods in determining pricing on consumer financing products with murâbahah schemes, namely: annuity method, and proportional method. (2) The construction of pricing formulation on consumer financing products with murâbahah schemes in BSM is based on: (a) The total monthly installments of customers, it is based on financing platfond, margin percentage and time peride, (b) The monthly principal installment of customers, it is based on total monthly installment and profit margin, (c) The monthly profit margin payment, is is based on platfond, principal installment, and margin percentage. (3) The formulation of pricing determination used by BSM as mentioned above needs to be revitalized because (a) including profitability return factor for customers, (b) the profit-taking formula used by BSM contains a gharar element, and (c) using the conventional bank paradigm in constructing its pricing formula.

Referring to the above conclusions, it can be suggested as follows: (1) For BSM in determining pricing on consumer financing with a murâbahah scheme must internalize sharia principles because the people will prefer to take financing at any bank that can provide a more equitable and Islamic profit despite they will face a big risk, (2) For customers that consumer financing with murâbahah schemes in BSM is not the same as conventional bank credit and can give a fairer and a more Islamic profit and also a lower risk level than credit in conventional banks. 


\section{References}

Anwar, Syamsul, 2007, Hukum Perjanjian Syariah: Studi tentang Teori Akad dalam Fikih Muamalah, Ed.1, Cet.1, Jakarta: PT. RajaGrafindo Persada.

Dusuki, Asyraf Wajdi, 2015, Sistem Keuangan Islam: Prinsip dan Operasi, Cet.1, Jakarta: PT. RajaGrafindo Persada.

Karim, Adiwarman A., 2007, Bank Islam: Analisis Fiqih dan Keuangan, Ed. 3-4, Jakarta: PT RajaGrafindo Persada.

Muhammad, 2014, Manajemen Keuangan Syari'ah: Analisis Fiqh \& Keuangan, Ed. I, Cet. I, Yogyakarta: UPP STIM YKPN.

Muhammad, 2014, 2016, Sistem Bagi Hasil dan Pricing Bank Syariah, Cet. I, Yogyakarta: UII Press Yogyakarta.

Sharia Mandiri Bank (BSM), 2017, "Consumer Banking Products", Internal Documents, Sharia Mandiri Bank, Sited from http//: www.syariahmandiri. co.id, on January 2.

Sharia Mandiri Bank (BSM), 2017, "Determination of Pricing with Murâbahah Contracts,", Internal Documents, Sharia Mandiri Bank, Sited from http//: www.syariah mandiri.co.id, on January 2.

Syaparuddin, 2016, The results of observations done on documents and public perceptions related to consumer financing products in the form of murâbahah contracts at the head office of BSM on May $1-31$.

Varberg, Dale E., 1992, Calculus with Analytic Geometry, New Jersey, USA: Prenctice-Hall. 